\title{
Preservice Teachers Learning Science Inquiry: eMentors Using Web 2.0 Learning Tools to Foster Student Inquiry
}

\author{
M. Randall Spaid and \\ Sumitra Himangshu \\ School of Education, \\ Macon State College, Macon, \\ GA, USA
}

randy.spaid@maconstate.edu; sumitra.himangshu@maconstate.edu

\author{
Stuart Fleischer \\ Walworth Barbour American \\ International School in \\ Israel, \\ Even Yehuda, Israel
}

stuartfleischer@gmail.com

\section{Extended Abstract}

In this descriptive study, the authors examined the online interactions of 45 teams of American International Schools (AIS) middle school students conducting science fair investigations with their distance mentors. Forty-five preservice teachers in a methods of teaching science college course served as "eMentors" using Blackboard" ${ }^{\mathrm{TM}}$ and the 2.0 Learning Tools (wiki and blog) as their individually assigned teams planned their projects, shared outcomes of their experiments, and analyzed the ir data.

eMentoring, as defined for this project, is the use of "computer conferencing systems to support a mentoring relationship when a face-to-face relationship would be impractical" (O'Neill, Wagner, \& Gomez, 1996, p. 39). The Near East South Asia Virtual Science Fair (NVSF) was designed to implement a science fair that encompasses hundreds of students, distance mentors, judges and teachers from eighteen American International Schools crossing geographic and geopolitical zones. Recognizing that today's middle schoolers are growing up in a dynamic digital environment, students easily master the technologies of chat, instant messaging, blogs, and a "virtual" science fair using Internet technologies and digital tools.

Using powerful elearning tools and eMentoring - pairing science educators and scientists with middle school students-helps establish content-related, curriculum-based "teleapprenticeships" (Levin, 1987), or what Riel \& Harasim (1994) refer to as "electronic mentorships." The NVSF is also a research effort, examining the nature of adult-child interactions and collaborative, asynchronous teaching and learning in primarily text-based, computer-mediated environments (Harris

Material published as part of this publication, either on-line or in print, is copy righted by the Informing Science Institute. Permission to make digital or paper copy of part or all of these works for personal or classroom use is granted without fee provided that the copies are not made or distributed for profit or commercial advantage AND that copies 1) bear this notice in full and 2) give the full citation on the first page. It is permissible to abstract these works so long as credit is given. To copy in all other cases or to republish or to post on a server or to redistribute to lists requires specific permission and payment of a fee. Contact Publisher@InformingScience.org to request redistribution permission.
\& Jones, 1999). The classroom teachers in each participating school help shape these interactions with the distance mentors.

While the teams of NVSF students designed and implemented their science experiments at home or in the science classroom, the e-learning component was transparently embedded into the process: teams communicated twice each week during the sixteen-week pro- 
ject by posting to a wiki, and reflected on what they were learning or challenged by posting to their blog. They posted questions to the eMentor, uploaded interim experiment reports, and shared their digital and photograph and video galleries. Most AIS students were excited when they found out that would be partnered with a university student, professor or scientist, and this enthusiasm was sustained as eMentors established rapport. Simultaneously, the eMentors had a unique opportunity to not only help collaborate on a research project, but also explore how a middle school student who may or may not speak English as a first language "thinks about science" in a rich exchange of knowledge.

Although there is no widely accepted operational definition of mentoring (Jacobi, 1991), effective mentoring relationships generally reflect several essential characteristics. They are helpful, personal, and reciprocal relationships that focus on achievement and provide emotional support (Freedman, 1993). Because the eMentoring relationship is computer-mediated, mentees and eMentors have a certain amount of anonymity that can facilitate more open exchange, a phenomena called the "strength of weak ties" (Granovetter, 1982; Levin \& Cross, 2002). Mentors need not be experts. Using technology enables a sense of empowerment, independence, ownership, mastery, and fluency of thinking (Russell, Bebell, \& Plati, 2001a); and it supports active engagement, participation in groups, frequent interaction and feedback, and connections to real-world contexts (Harasim, 1990; Roschelle, Pea, Hoadley, Gordin, \& Means, 2000). The integration of appropriate technology, in this case the wiki and blog, was critical to the success of eMentoring in this study.

This study was an instrumental, collective case study (Stake, 2000). It was instrumental because we were interested in the implications of eMentoring as an intervention 1) to improve the science inquiry activities of diverse AIS middle school students and 2) to enhance the ability of preservice college students preparing to become effective elementary school teachers to respond to and interact with students of a different culture and/or language during science inquiry activities. It was collective because individual cases (each eMentor-mentee relationship) shared common characteristics such as all eMentors were preservice teacher candidates and all mentees were middle school students, and individual cases were "chosen because it is believed that understanding them will lead to better understanding about a still larger collection of cases" (Stake, 2000, p. 47).

Data for this study were gathered for 45 teams of AIS students in sixth, seventh, or eighth grade, from twelve countries and multiple first languages. eMentors: Forty-five undergraduate preservice elementary education teachers candidates served as eMentors. The undergraduate students were primarily first semester juniors and ranged in age from 23 to 35, and all were enrolled in a science content and teaching methods required course for teaching certification. Each undergraduate mentored one team of AIS students. Prior to beginning the study, eMentors were instructed in methods of process science inquiry activities, effective ways of teaching science inquiry activities, and useful ways of providing feedback. During the study, a continuous feedback loop between AIS classroom teacher, NVSF technology specialist, college professor, and eMentors focused responses to mentee postings in keeping with time constraints, classroom teacher's needs, and students' needs.

The postings were evaluated for number of words and incorporation of eMentor feedback during subsequent posts to delineate language conventions, content, organization, and style and voice. EMentors' responses were coded for the quality of feedback which broke down into feedback that addressed language conventions, content, style and voice, and organization, whole text feedback vs. focused feedback, the level of language difficulty used while providing feedback, honesty of feedback, and ability to engage students in their investigation, etc. 
Exchanges between eMentors and mentees were also examined for the characteristics of the mentoring relationship. Initial codes included self-reported comments about science inquiry activities for mentees and teaching science inquiry activities for eMentors, events that indicated degrees of respect and openness between eMentor and mentees, and discussion of issues not related to school or science inquiry activities.

Of the total number of messages exchanged, $76.4 \%$ (367) were posted by eMentors and NVSF team members who communicated during the full sixteen-week project, and $33.6 \%$ (113) were posted by the other eMentors and their teams for a shorter interval. Only full sixteen-week collaborations were used for message function and flow analysis. It is important to note that the numbers of messages and average message length in words were not consistently related.

The functions, frequency, and flow of exchanges were analyzed based on Rueda's (1992) taxonomy; results indicated that: (1) eMentors "talked" more in during the project than their mentees, even though students' inquiry was the focus of the NVSF; (2) participants' roles as eMentor or student were associated with greater and lesser frequencies of certain message function types, e.g., requests for help (78\%), response to eMentor feedback (8\%); and (3) requests or reports directly related to curriculum content comprised a surprisingly small portion of total message functions identified.

Messages flowed from eMentors to their mentees (63.8\%) and students to their eMentors (36.2\%) in proportion to total messages exchanged. Message lengths for all flow patterns ranged between 20 and 256 words, with an overall mean length of 42.16 words and a standard deviation of 85.05 words. Of all postings, eMentors sent the longest messages, especially when they were assisting their teams with background information, and students sent the shortest messages, except when they were reporting experiment results to their eMentors.

More than $90 \%$ of all posts contained some information reporting. Approximately $50 \%$ of all messages requested information. Almost $80 \%$ of all posts also showed evidence of salutation, planning, complaining, apologizing, thanking, or some combination of these function types. Of all postings by eMentors and their mentees, $56 \%$ contained requests for content information and non-content-related directions. Although 34\% of all posts by eMentors contained requests for content, only $12 \%$ of their mentees posted a content-rich "reply." This is probably because mentees often replied with a concern about time constraints due to other school activities. Very few posts contained complaints (2\%), and many more contained expressions of gratitude (18\%). The teams seemed to interact in friendly, respectful ways.

Several important lessons emerged from this research that address 1) difficulties of the multicultural context, i.e., English Language Learners; 2) the effectiveness of eMentoring in improving science inquiry; 3) importance of preservice teachers learning to provide effective feedback; and 4) the affective component of online mentoring. The evaluation shows that the NVSF project not only engaged diverse students in science learning in ways that students themselves found more powerful than the typical science classroom, but als o taught students 21 st century skills. The preservice teachers increased their pedagogical content know ledge to successfully establish a mentoring relationship with the multicultural middle school students, and helped struggling students improve their inquiry skills. A collaborative technology model between the college student eMentors and the middle school classroom teachers improved the science skills for "at-risk" students. Additionally, the project prompted the college students to self-reflect as evolving teachers while broaching some of the challenges of using Web 2.0 tools.

Keywords: Web 2.0, distance mentoring, preservice teachers, science inquiry 


\section{References}

Harris, J. (1995). Organizing and facilitating telecollaborative projects. The Computing Teacher, 22(5), 6669.

Harris, J. B, \& Jones, G. (1999). A descriptive study of telementoring a mong students, subject matter experts, and teachers: Message Flow and Function Patterns. Journal of Research on Computing in Education, 32(1), 36-53.

Levin, J. A. (1987). Education on the electronic frontier: Teleapprentices in globally distributed educational contexts. Contemporary Educational Psychology, 12, 254-260.

Nellen, T. (1998). EMentoring Web: Adult experts in the classroom. Retrieved from http://mbhs.bergtraum.k12.ny.us/mentor/

Nellen, T. (1999). Morphing from teacher to cybrian. Multimedia Schools, 6(1), 27-29.

O'Neill, D. K., Wagner, R., \& Go mez, L. M. (1996). On line mentors: Experimenting in science class. Educational Leadership, 55(3), 39-42.

Riel, M., \& Harasim, L. (1994). Research perspectives on network learning. Machine-Mediated Learning, 4,91-113.

Rueda, R. S. (1992). Characteristics of teacher-student discourse in computer-based dialogue journals: A descriptive study. Learning Disability Quarterly, 15, 187-206.

Stake, R. E. (2000). Case studies. In N. K. Denzin \& Y. S. Lincoln (Eds.), Handbook of qualitative research: Second edition (pp. 435-454). Thousand Oaks, CA: Sage.

Zeeb, P. (2000). Mentoring distance learners. Distance Education, 4(7), 6-7.

\section{Biographies}

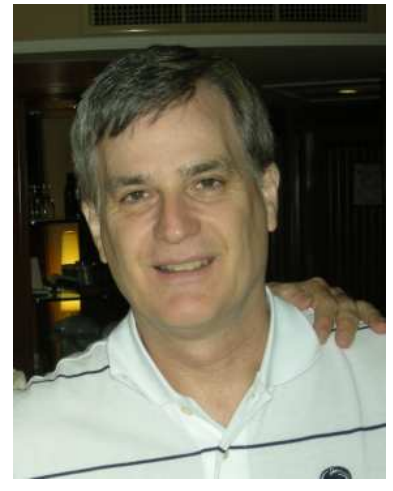

Dr. M. Randall Spaid is an Associate Professor of Education at Macon State College's School of Education. He directs the secondary teacher certification program and teaches undergraduate courses in science content and methods of teaching science infusing technology. He is the Principal Investigator for the NESA Virtual Science Fair Project and has directed several teacher professional development grants. Dr. Spaid has twenty-four years experience as a high school teacher using technology and has extensive experience developing curriculum, training teachers, presenting at professional conferences, and publishing articles. He earned a Ph.D. in Curriculum \& Instruction at Florida State University

Sumitra Himangshu is an Assistant Professor of Education at Macon State College.

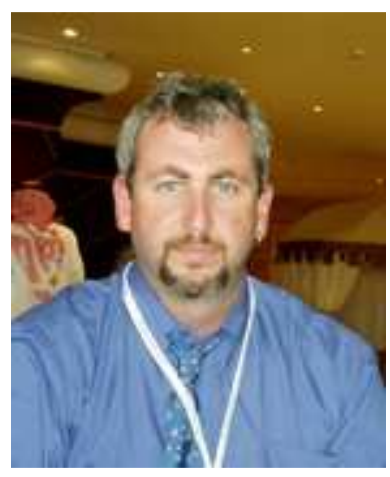

Stuart Fleischer is presently teaching science at the American International School in Israel and is a guest lecturer at Tel Aviv University teaching ecology to overseas students. Dr. Fleischer has an undergraduate degree in microbiology from the University of Tennessee and received his masters, specialist and doctoral degrees in science education from Florida State University. He began teaching at WBAIS-Israel in 1991. 
Dr. Fleischer became interested in embedding e-learning technology into his curriculum about 15 years ago when he participated and consulted for an internet-based peace project called "Migrating Birds Know No Boundaries" which is chaired by Nobel Prize winner Shimon Peres and former U.S. Vice-President and Nobel Prize winner Al Gore. Since then, he has created a variety of projects, led workshops in 12 countries and consulted on innovative uses of online technologies in education. Presently, Stuart Fle ischer serves as the project director for the NESA Virtual Science Fair for 5th grade and the middle school and currently oversees participating schools in around the globe with over 2,000 students from 75 countries speaking over 50 languages. 